\title{
Five Drivers Affect the Health of the Planet
}

GEO-6 identifies five drivers affecting the health of the planet. The trends in human population and demographics combined with economic development, and the growth of consumption that this can enable, have been acknowledged for many decades as the primary drivers of environmental change (well established). More recently, rapid urbanization, accelerating technological innovation, and climate change have been identified as additional drivers. There are wide disparities globally in the consumption and production patterns linked to those drivers. $\{2.1 .1,2.2$; SPM, p. 6\}

\subsection{Population Dynamics}

The global population in $\mathbf{2 0 1 8}$ was 7.5 billion, with median projections estimating an increase to nearly 10 billion by 2050 and nearly 11 billion by 2100 (well established). Increases in life expectancy, and reductions in infant and other mortality, mean population growth rates will remain positive in all regions except Europe and certain parts of Asia. Unequal access to education (Figure 2.1) and lack of empowerment of women, as well as women's lack of access to sexual and reproductive health services, all contribute to high birth rates. $\{2.3\}$

Population growth is expected to be highest in countries that are very poor, have a low carbon footprint per capita, and have high gender inequity in terms of

Figure 2 .1: Female secondary education and total fertility rates

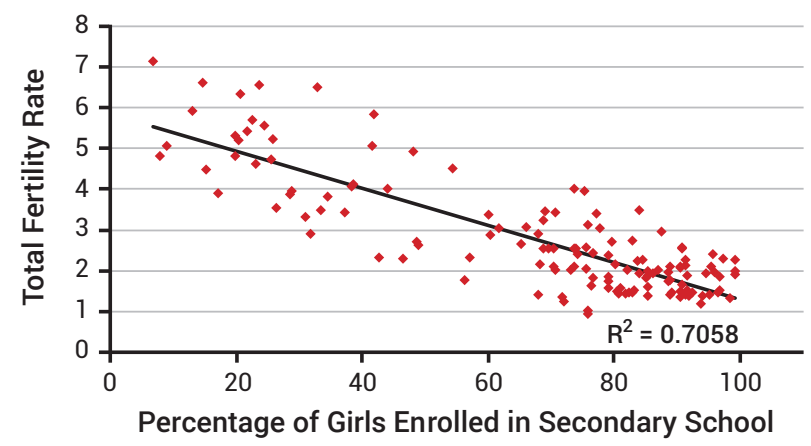

Source: Earth Policy Institute (2011). access to education, work, and sexual and reproductive rights and health services (well established). $\{2.1,2.3$, 2.3.4, 2.1.1; SPM, p. 6\} Such countries also have a low carbon footprint per capita (well established). \{Chapter 2, ExecSum, 2.1, 2.3.1, 2.3.2; Co-Chairs' Message\}

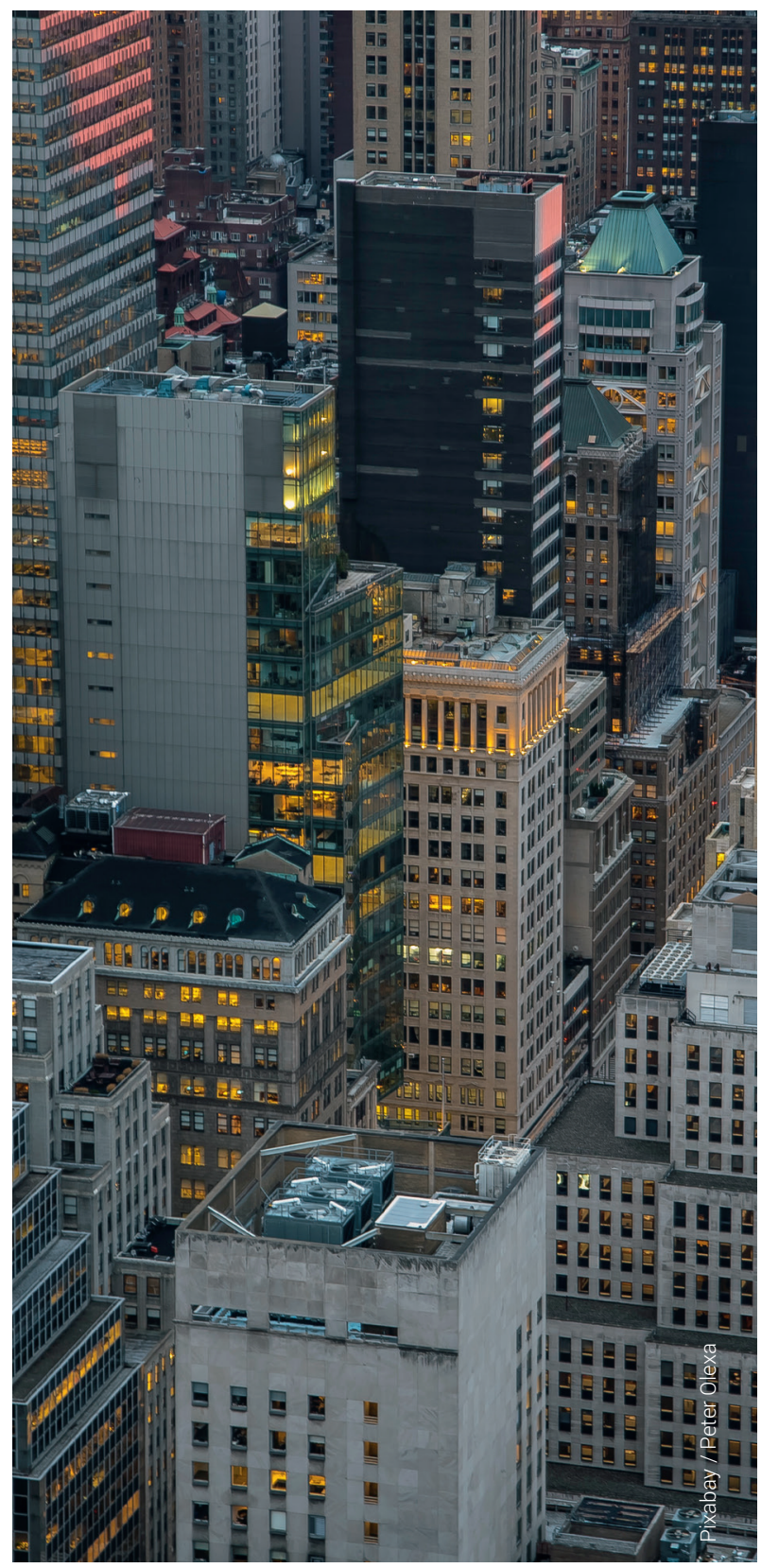


Population growth will remain important in countries experiencing an early or late demographic dividend ${ }^{1}$ (most middle-income and upper middle-income countries) (Figure 2.2). These are also the countries that are projected to have the highest increases in carbon footprints per capita and in environmental footprints more broadly. \{Chapter 2, ExecSum, 2.3.1\}
The world population will become older on average (including in the global South), will become more urban, and will live in smaller households (well established). The trend of rapid urbanization is mainly in the global South.

\section{Figure 2.2: World population, emissions and fertility}

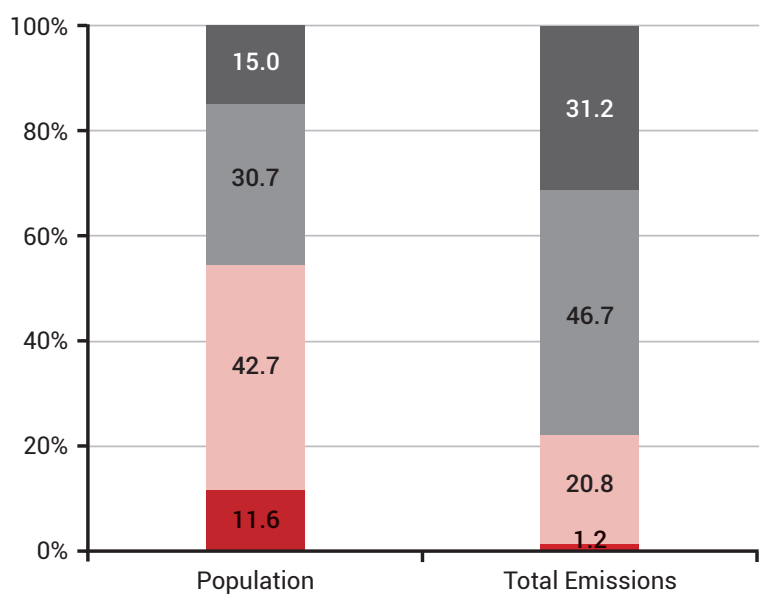

Pre-demographic dividend

Early-demographic dividend

Late-demographic dividend

Post-demographic dividend
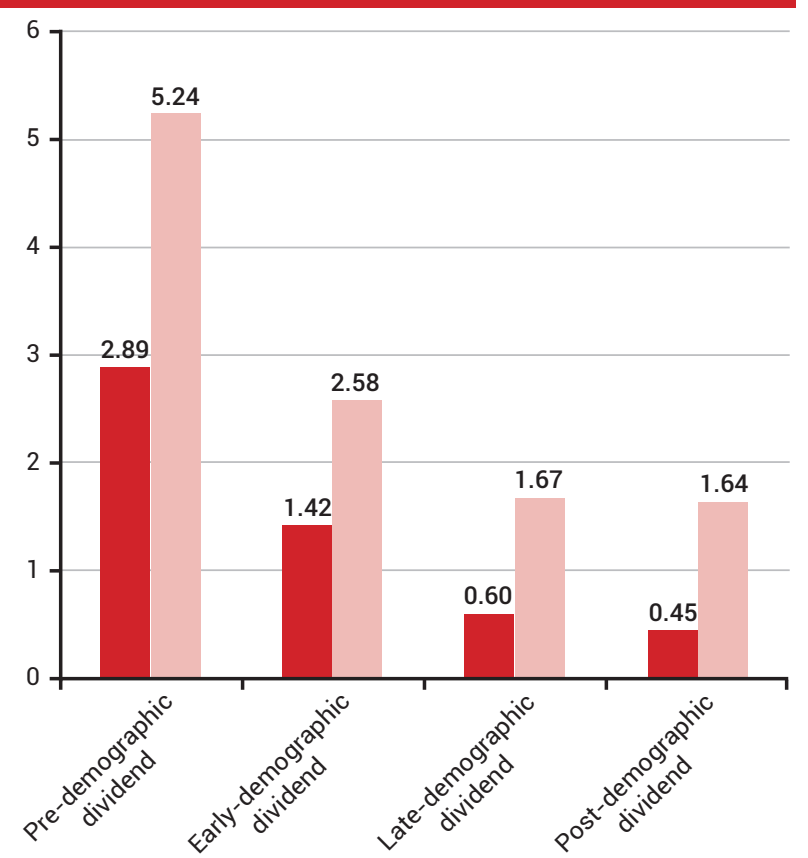

Population growth $\quad$ Fertility rate

Source: Own elaboration based on World Development Indicators, World Bank (2017).

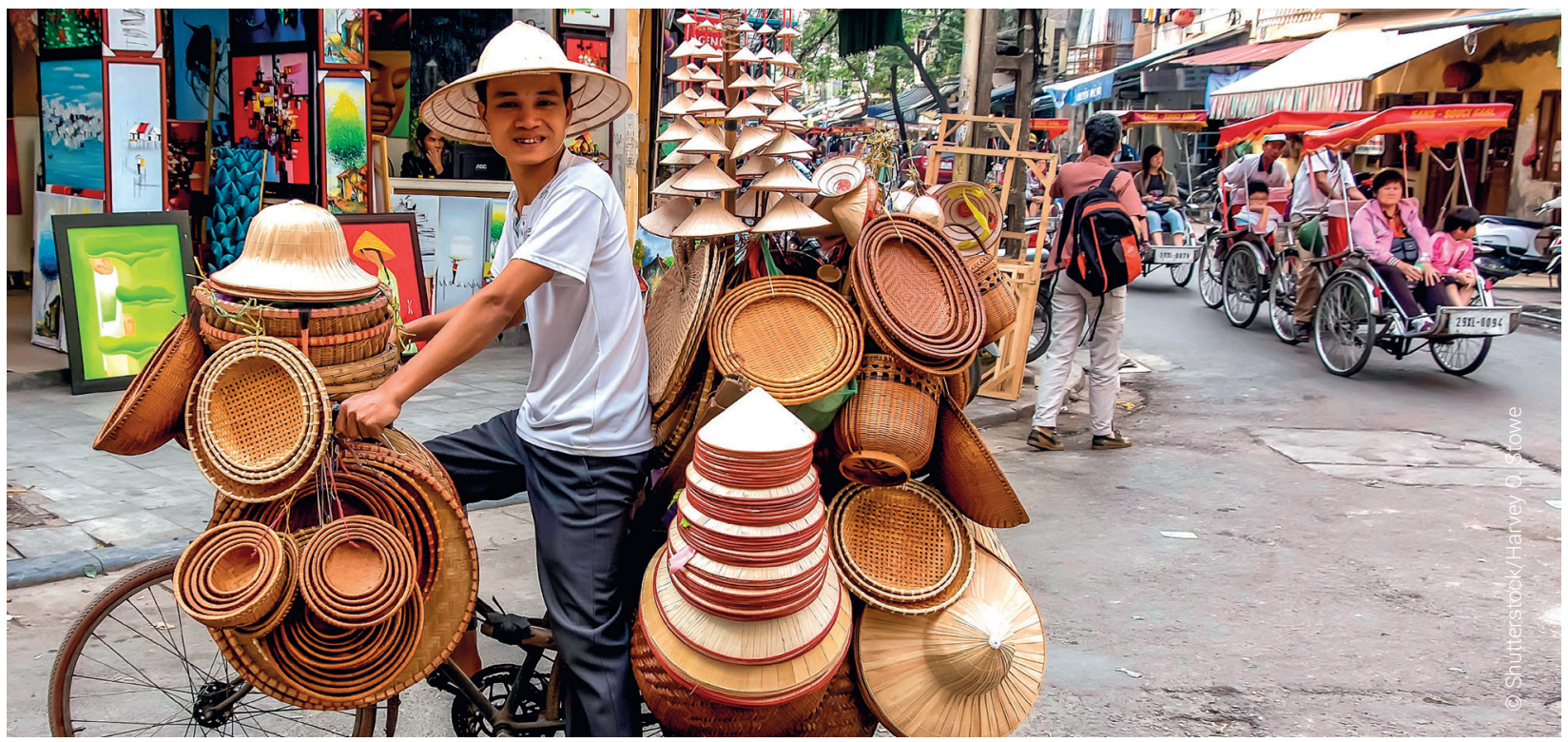

The demographic dividend is the economic growth potential that can result from shifts in a

population's age structure, mainly when the share of the working-age population is larger than the non-working-age share of the population. 


\subsection{Economic Development}

Economic development has lifted billions of people out of poverty and improved access to health and education in most regions of the world (well established). Although income levels in developing countries lag behind those of developed countries, growth rates in the former are now outstripping growth rates in the developed world (Figure 2.3) and the welfare of large numbers of people is improving.

The "grow now, clean up later" economic approach is still widely followed despite the economic, environmental, human and social costs it imposes - often on the most disadvantaged in society (well established). Such an approach will not sustainably support 10 billion healthy, fulfilled and productive people in 2050. Sustainable development requires that economic development and environmental protection go hand-in-hand. $\{2.5 .1$; SPM, p. 6$\}$

Economic development in the past has driven increased resource use, harmful emissions and other causes of environmental damage (well established). Economic growth and development continues to be the number one policy priority in most countries because of its material benefits and its contribution to employment and social cohesion. However, the negative effects of economic growth on the environment are increasingly costly, sometimes impossible to remedy, and threaten to reverse many of the past achievements of economic development. \{Chapter 2, ExecSum, 2.5.1, 2.5.4\}

\subsection{Urbanization}

Urbanization influences the nature and magnitude of environmental and development outcomes (well established). People who live in urban areas generally have higher incomes and better access to political power. They also experience higher rates of economic growth. Per capita, their consumption rates are higher and they place greater pressure on natural resources. Cities use resources more efficiently per unit of income generated, and they have better potential for energy efficiency. Cities are also engines of economic growth: no country has made the transition from poverty to middle-income status without a period of rapid urbanization. Urbanization is generally associated with better access by women to reproductive health and economic capacities and choices, often resulting in lower fertility rates among urban women than those in rural areas. Managed effectively, urbanization can help achieve the SDGs efficiently and sustainably. $\{2.4\}$

\section{Figure 2.3: How economic growth rates in developing countries began to outstrip those in developed countries}

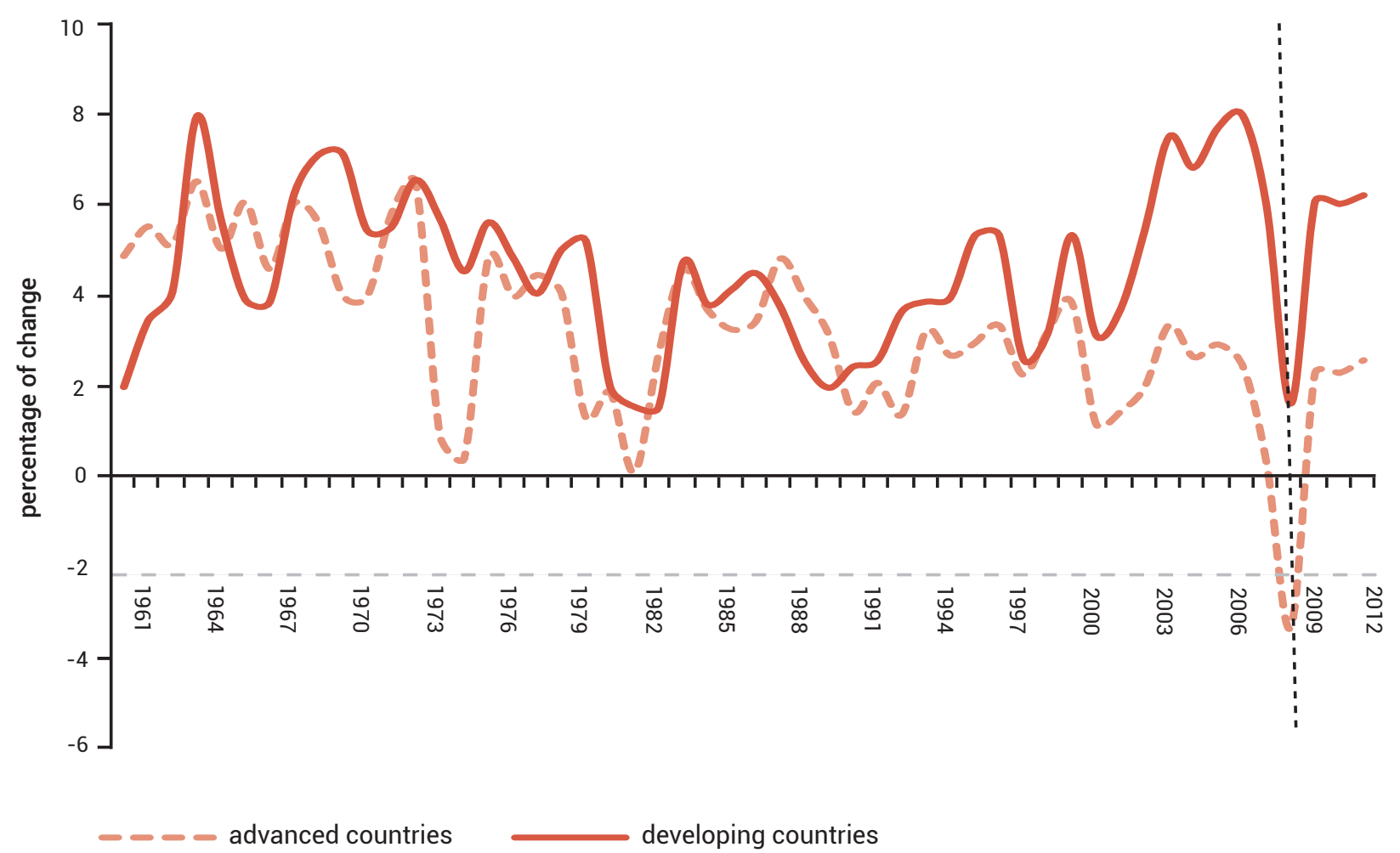

Source: Canuto (2010). 


\section{Urban footprints have transboundary ramifications} (well established). The magnitude, scale and scope of contemporary urbanization is affecting global resource flows and planetary cycles. Current urbanization processes and prospects are not only a challenge; they also present an opportunity to improve human well-being with potentially decreasing environmental impacts per capita and per unit of production through sustainable urbanization. \{Chapter 4, ExecSum, 4.2.5\} Lower-impact urban lifestyles and economies can be facilitated through improved governance, infrastructure and services; sustainable land-use planning; and technological opportunities. At the same time, investment in rural areas can reduce pressure to migrate and rates of urbanization. $\{2.4 .4,17.3 ;$ SPM, p. 6$\}$

\section{Urbanization is taking place at an unprecedented rate} globally, and cities have become the foremost drivers of economic development (well established). The average rate of urbanization globally between 1990 and 2015 was 2.3 per cent. If the relative change in the degree of urbanization is disaggregated by income class for this period, it can be seen that in Asia low-income countries (LICs) have been urbanizing at the fastest rates (15.5 per cent) in comparison with low to middle-income countries (LMCs) (1.2 per cent) and upper middleincome countries (UMCs) (1.5 per cent). A similar pattern is seen in Africa (where the urbanization rates are 8 per cent for LICs, 3.6 per cent for LMCs and 5.7 per cent for UMCs) and in Latin America and the Caribbean (Melchiorri et al. 2018). \{2.4.2\}

While megacities are economic powerhouses, the majority of the global urban population does not live in them. More people, especially in emerging and developing economies, live in smaller cities and towns (Figure 2.4). By 2050 the share of the urban population in the total world population is expected to rise to 66 per cent (well established). Around 90 per cent of the growth in the urban population will take place in developing countries (United Nations Human Settlements Programme [UN-Habitat] 2014a). Africa, the most rapidly urbanizing region, is expected to experience the highest urban population growth (well established). European cities grew least rapidly in the period 19952015 (UN-Habitat 2016a). Migration is the critical factor accounting for increased urbanization rather than fertility or age structure, which are, respectively, lower and older in urban areas (UN-Habitat 2016a). \{2.4, 2.4.3; SPM, p. 6$\}$

Small and medium-sized cities account for roughly 50 per cent of the world's urban population and their populations are growing at the fastest rate (well established). According to UN-Habitat, these cities will "deliver nearly 40 per cent of global (urban population) growth by 2025, more than the entire developed world and emerging market megacities combined". Small

Figure 2.4: Global urban population growth propelled by cities

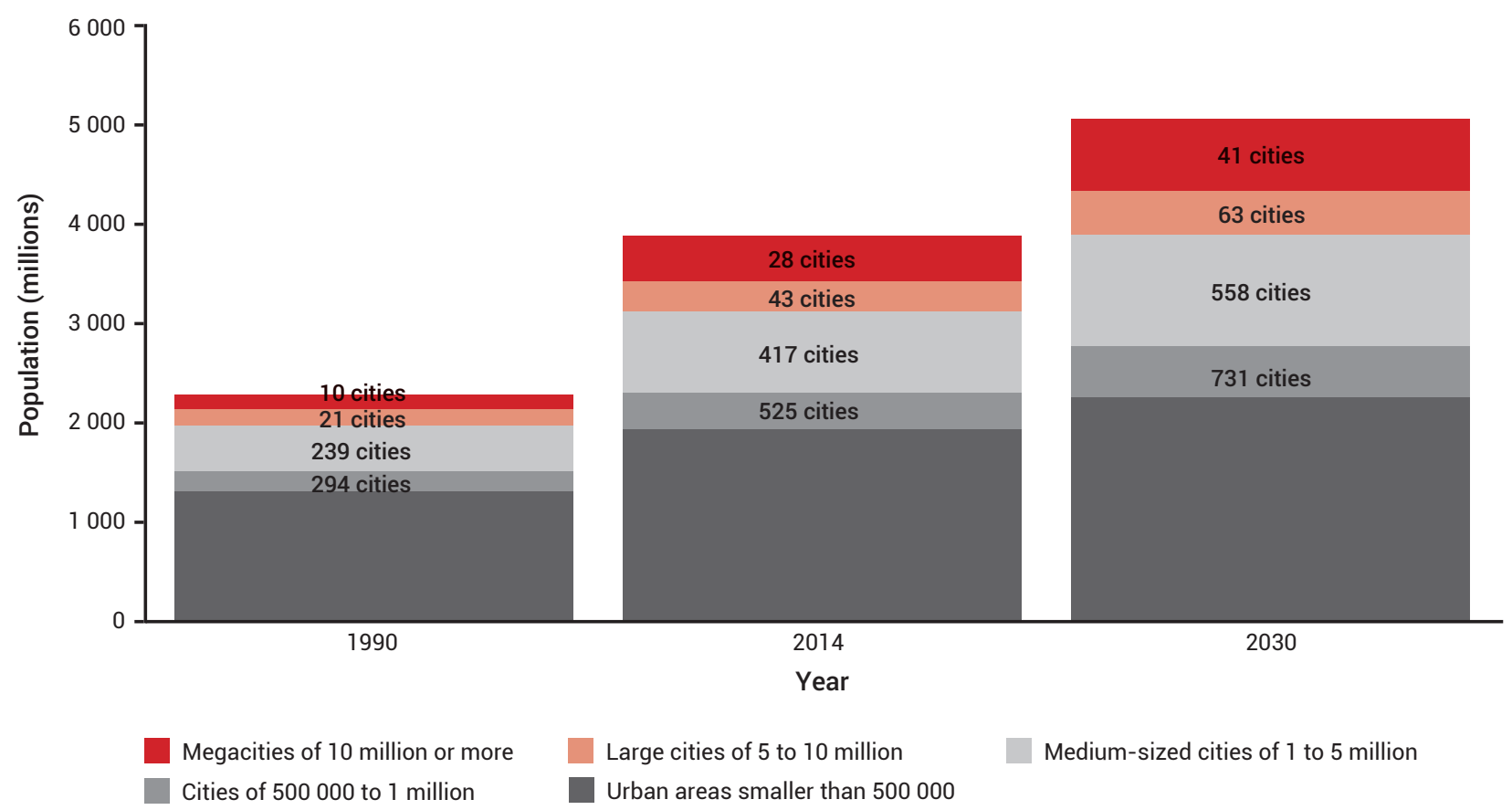

Source: United Nations (2014, p. 13). 
and medium-sized cities are more vulnerable to natural hazards than large cities and megacities. Cities of medium to very high vulnerability are growing fastest

(Figure 2.5). Many small and medium-sized cities "lack the technical capacity to lead a major urban development process" (UN-Habitat 2012, p. xiv) and have devolved responsibilities without corresponding resources, hampering their capacities to plan and manage growth and supporting infrastructure. The result is that the ability of urban governments to protect both natural resources and the rights of their citizens is severely circumscribed. $\{2.4 .2\}$

Figure 2.5: City growth rates and urban vulnerability

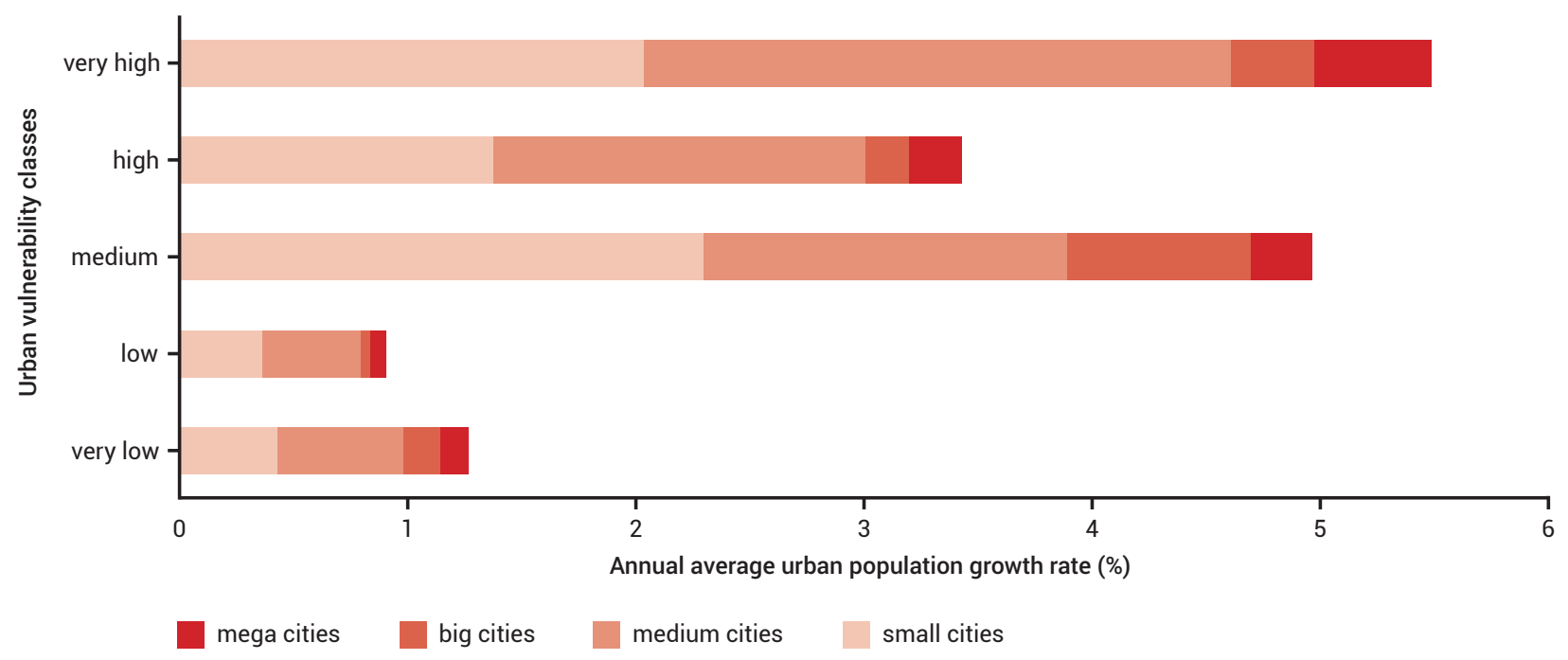

Source: Birkmann et al. (2016).

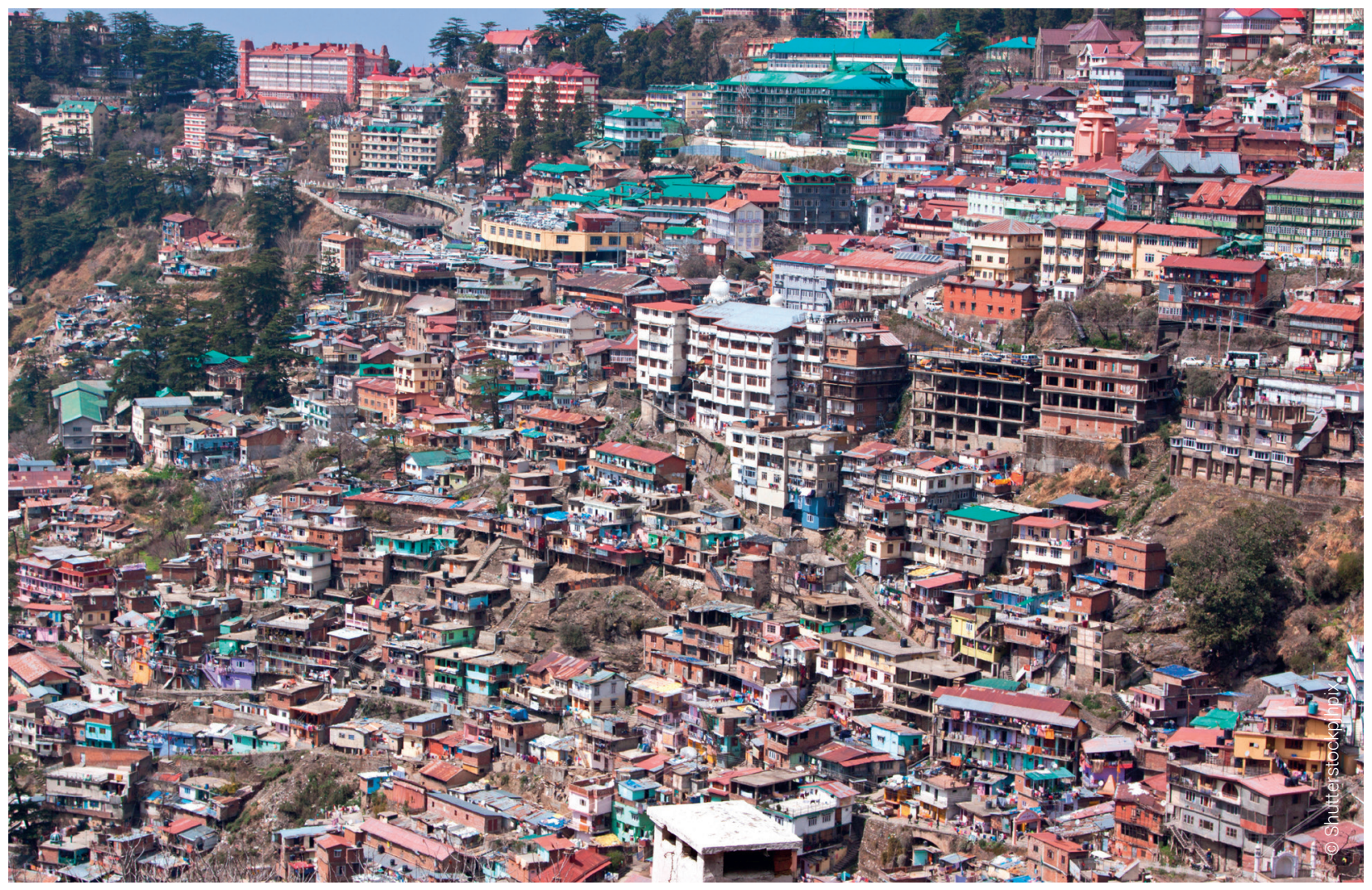


Built-up area

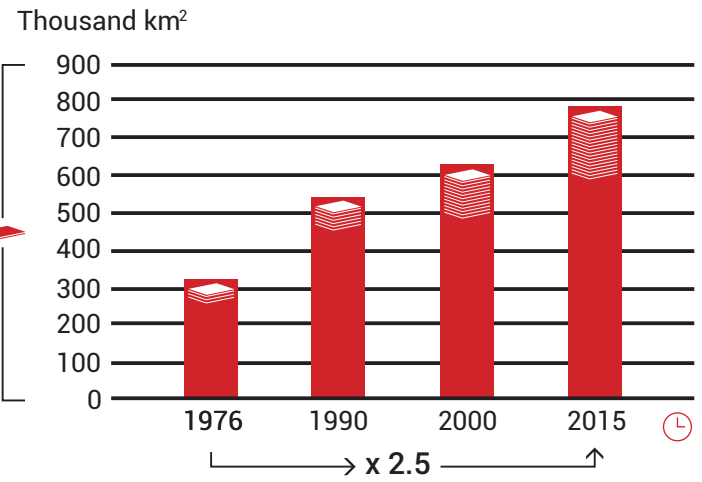

In the last 40 years built-up area increased by approximately 2.5 times

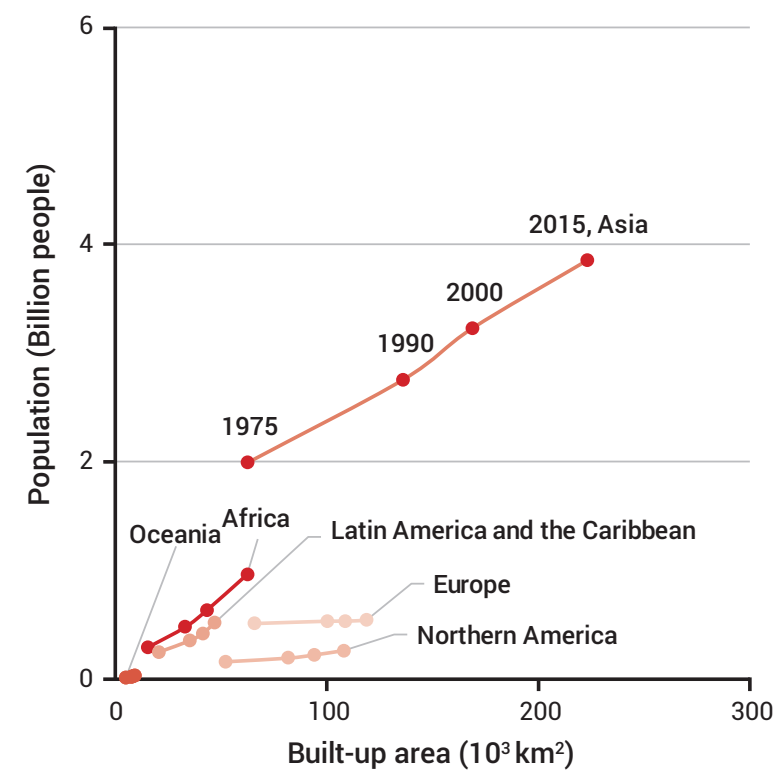

Source: Pesarasi et al. (2016).

Globally, the built-up area has grown faster than the population. However, the extent of the built-up area varies according to region (Figure 2.6) (well established).

Serious social and environmental challenges of urbanization remain unmet in many urban areas, particularly (but not only) in the global South (well established). Urbanization has been accompanied by increases in informal urban populations (Figure 2.7), many of which lack access to basic services. Some 30 per cent of urban residents globally do not have access to basic services or social protection, with poor

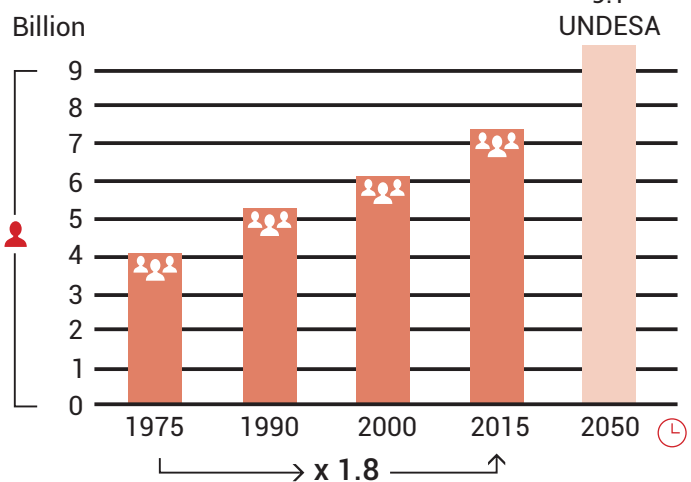

In the last $\mathbf{4 0}$ years population increased by 1.8 times

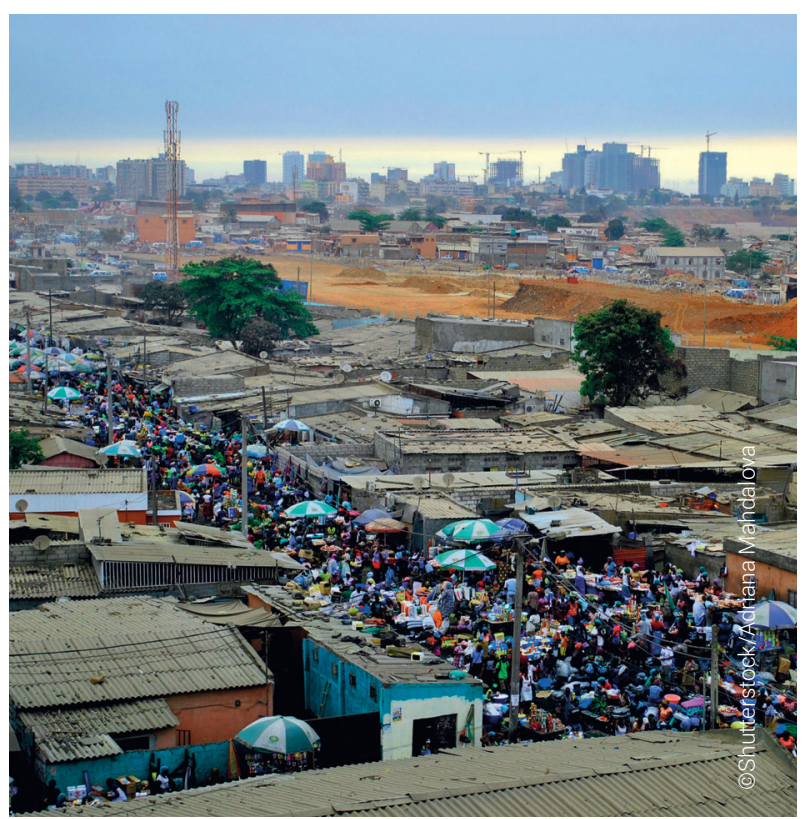

women in low-income urban neighborhoods especially vulnerable. $\{2.4,2.4 .3$; SPM, p. 6$\}$ These challenges will be exacerbated by climate change, as well as by rapid urban growth in cities and regions that currently lack the capacity to manage and adapt to these mounting pressures. $\{2.4\}$

Almost all coastal cities of any size, particularly those in small island developing states (SIDS), are increasingly vulnerable to rising sea levels, floods and storm surges caused by climate change and extreme weather events (established but incomplete). In general, 
Figure 2.7: World urbanization trends

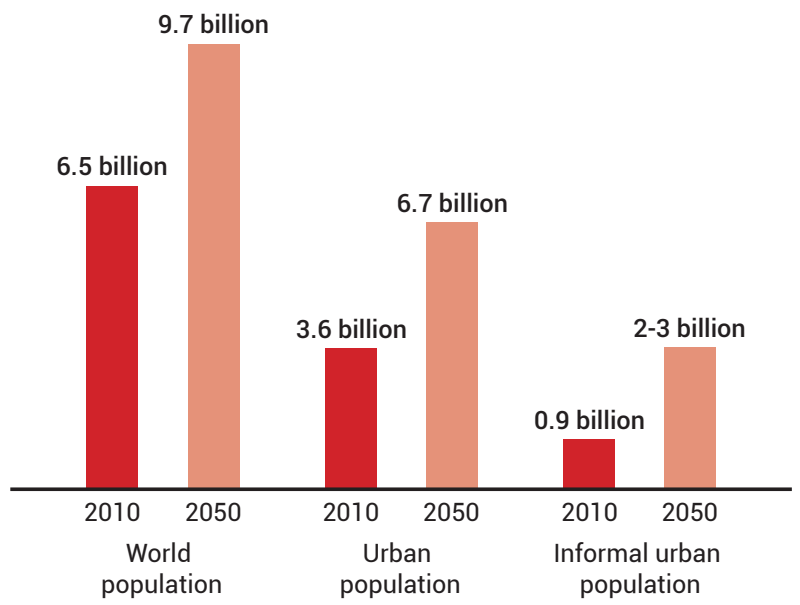

Source: Own elaboration based on UN-Habitat (2014b); UN-Habitat (2016a); UN-Habitat (2016b); United Nations (2018).

the cities in developing countries that are urbanizing most rapidly are the most vulnerable to these pressures. $\{2.4 .4,17.3 ;$ SPM, p. 6$\}$

The coming decades will be crucial. The current period of global urbanization has not just been dramatic, but also very quick. It took 200 years for the urban share of the world's population to increase from 3 per cent (around 30 million people) to 50 per cent ( 3.5 billion people in 2010) (United Nations 2014). With the world's urban population expected to increase to 6.7 billion by 2050 (Figure 2.7), some models estimate that urban infrastructure could more than double by 2030 based on the 2012 urban area. $\{2.4,2.4 .3$; SPM, p. 6$\}$

\subsection{Climate change}

Climate change is a priority issue, affecting human and natural systems directly and altering the complex interactions among them (well established). Historical and ongoing greenhouse gas (GHG) emissions and rising mean atmospheric carbon dioxide $\left(\mathrm{CO}_{2}\right)$ concentrations (Figure 2.8) are propelling us towards a global future with an extended period of climate change (well established). Climate change is causing warming of the air and ocean; rising sea levels; melting glaciers, permafrost and Arctic sea ice; changes in carbon, biogeochemical and global water cycles; food security crises; freshwater scarcity; and more frequent and more extreme weather events such as storms and wildfires. Higher atmospheric and marine concentrations of $\mathrm{CO}_{2}$ also lead to ocean acidification and affect the composition, structure and functionality of ecosystems. The types of impacts listed above are becoming increasingly dangerous. Climate change is therefore a global driver of environmental, social, health and economic impacts and heightened society-wide risks. Unless GHG emissions are radically reduced, the world is on course to exceed the temperature threshold set out in the Paris Agreement under the United Nations Framework Convention on Climate Change (UNFCCC). $\{2.7 .3$; SPM, p. 6$\}$

Figure 2.8: Mean atmospheric $\mathrm{CO}_{2}$ concentrations

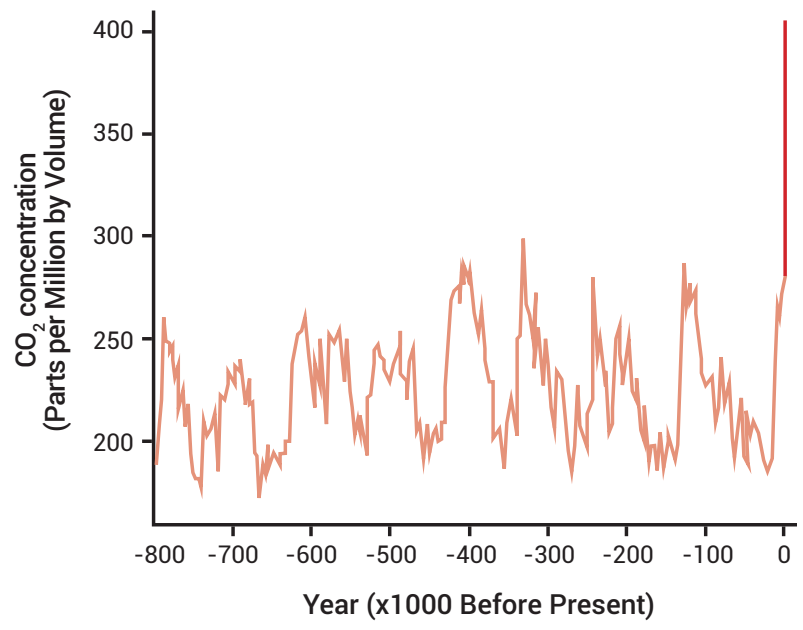

Source: Based on (light red) NOAA data from https://www.ncdc.noaa.gov/ data-access/paleoclimatology-data and (in red) data provided by Pieter Tans, NOAA/ESRL (www.esrl.noaa.gov/gmd/ccgg/trends/ and scrippsco2.ucsd. edu/))

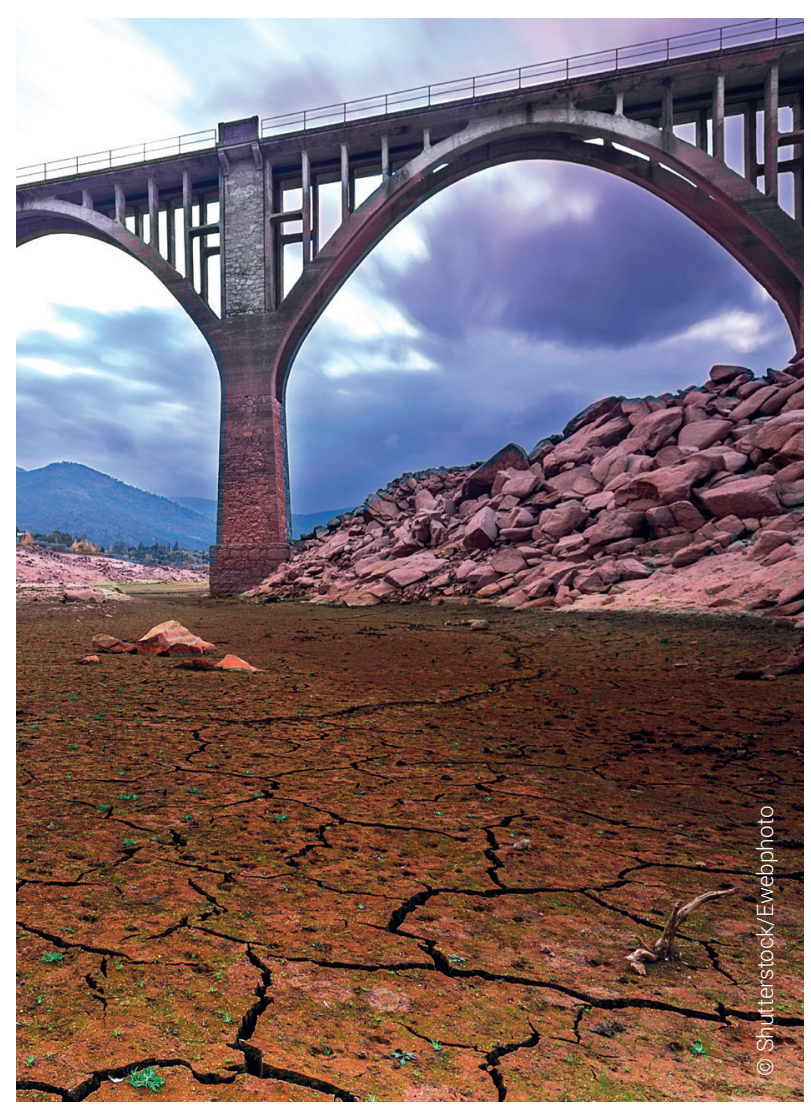




\section{Countries vary widely in their production of GHG} emissions (well established). Figure 2.9 shows emission trends for selected countries in the period 1990-2015. The richest 10 per cent of the world population emits 45 per cent of total GHG emissions, while the poorest 50 per cent emits only 13 per cent (Figure 2.9). Patterns of wealth and lifestyles associated with GHG emissions also reflect other social inequalities, including those related to gender and race/ethnicity.
Climate change presents a serious challenge to future economic development (well established). As the climate impacts already under way continue to increase, countries will incur heavy social and economic costs (Figure 2.11 and Figure 2.12), \{Chapter 2, ExecSum, 2.7.1, 2.7.2\}

\section{Figure 2.9: Emission trends in different countries from 1990 to 2015: red lines show growth and blue lines show}

reductions

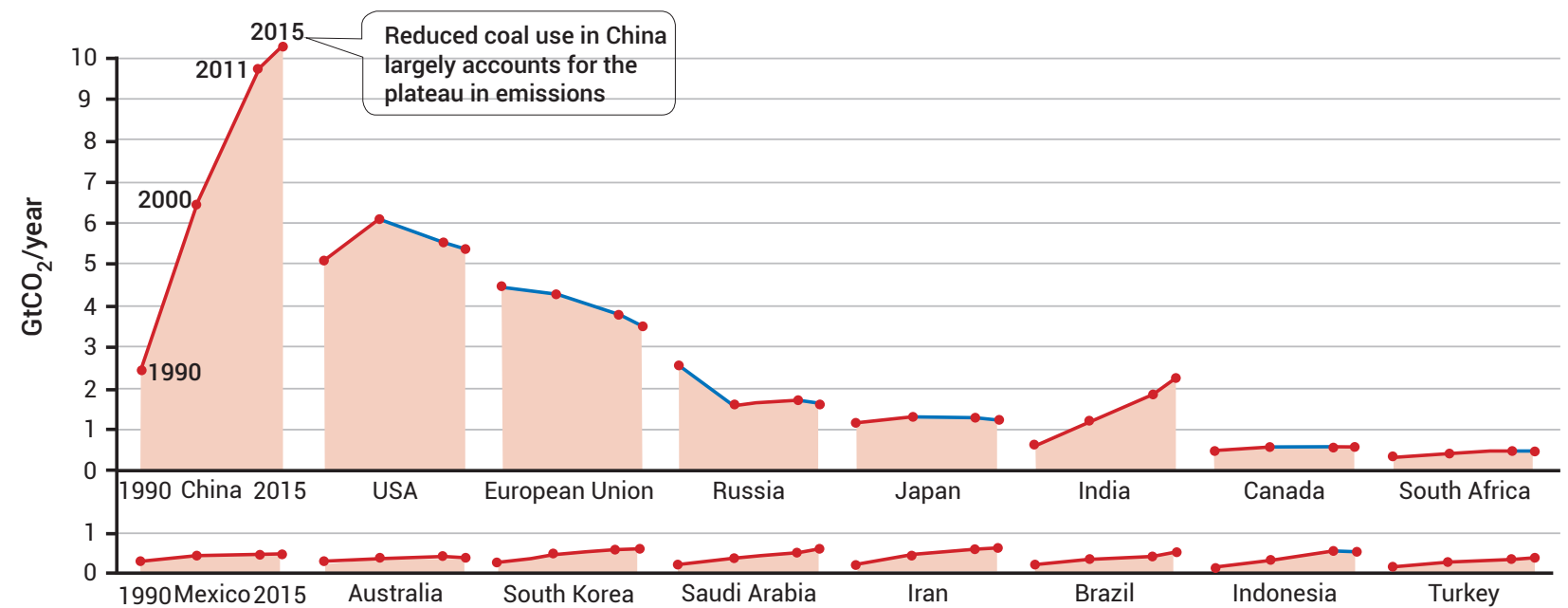

Source: Le Quéré et al. (2016).

\section{Figure 2.10: Consumption and associated environmental pressures are unequally distributed across nations}

Top $10 \%$ emitters: $45 \%$ of world emissions

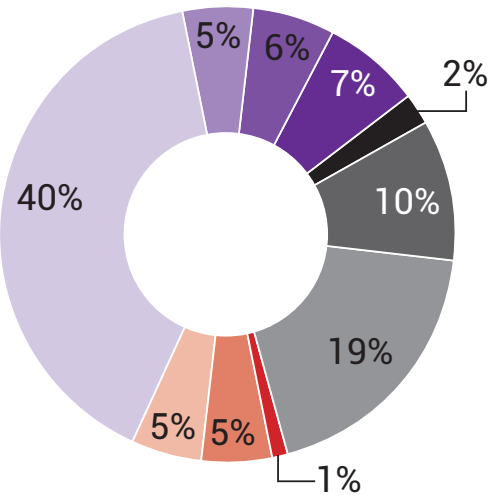

India

MENA

Other Asia

Russia/C. Asia

China

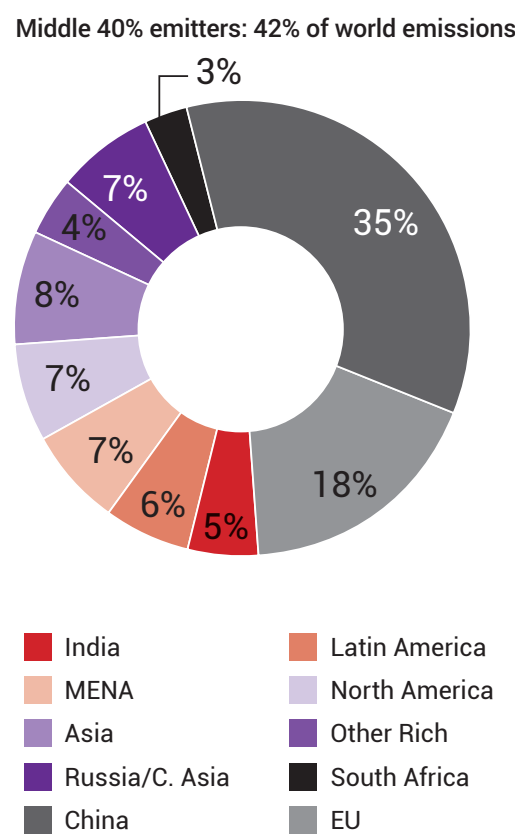

Bottom $50 \%$ emitters: $13 \%$ of world emissions

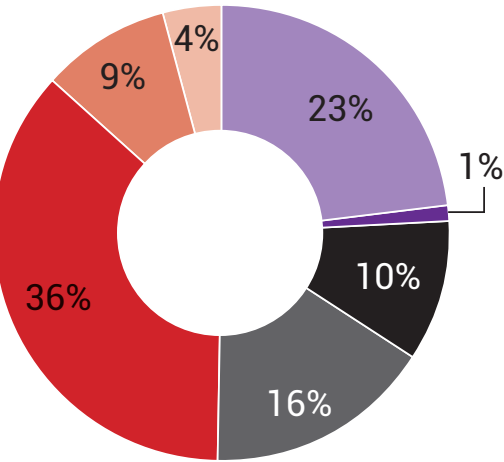

India

MENA

Russia/C. Asia

China

Source: Chancel and Piketty (2015). 


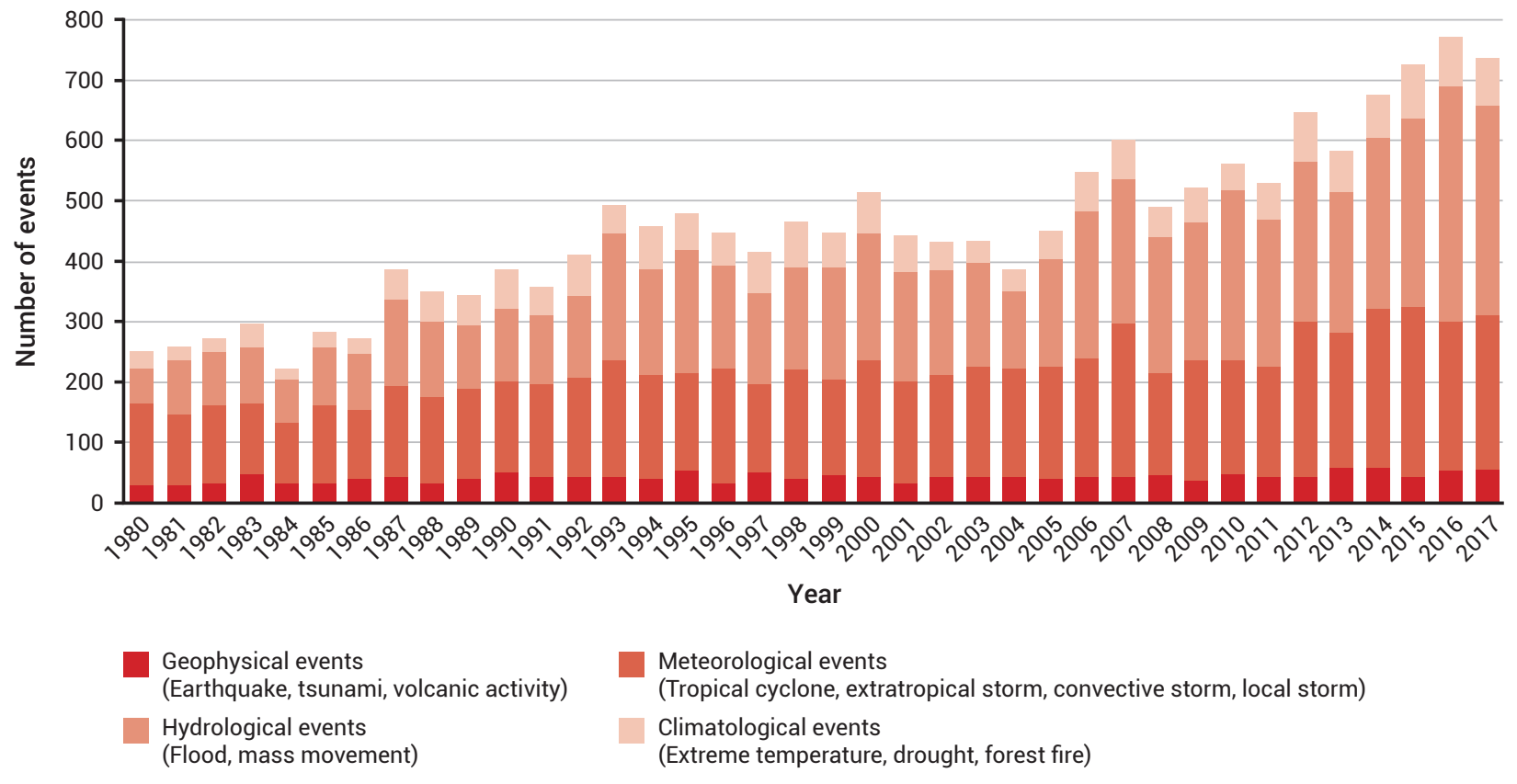

Source: Munich Re (2017).

Figure 2.12: The economic and human impact of disasters from 2005-2014

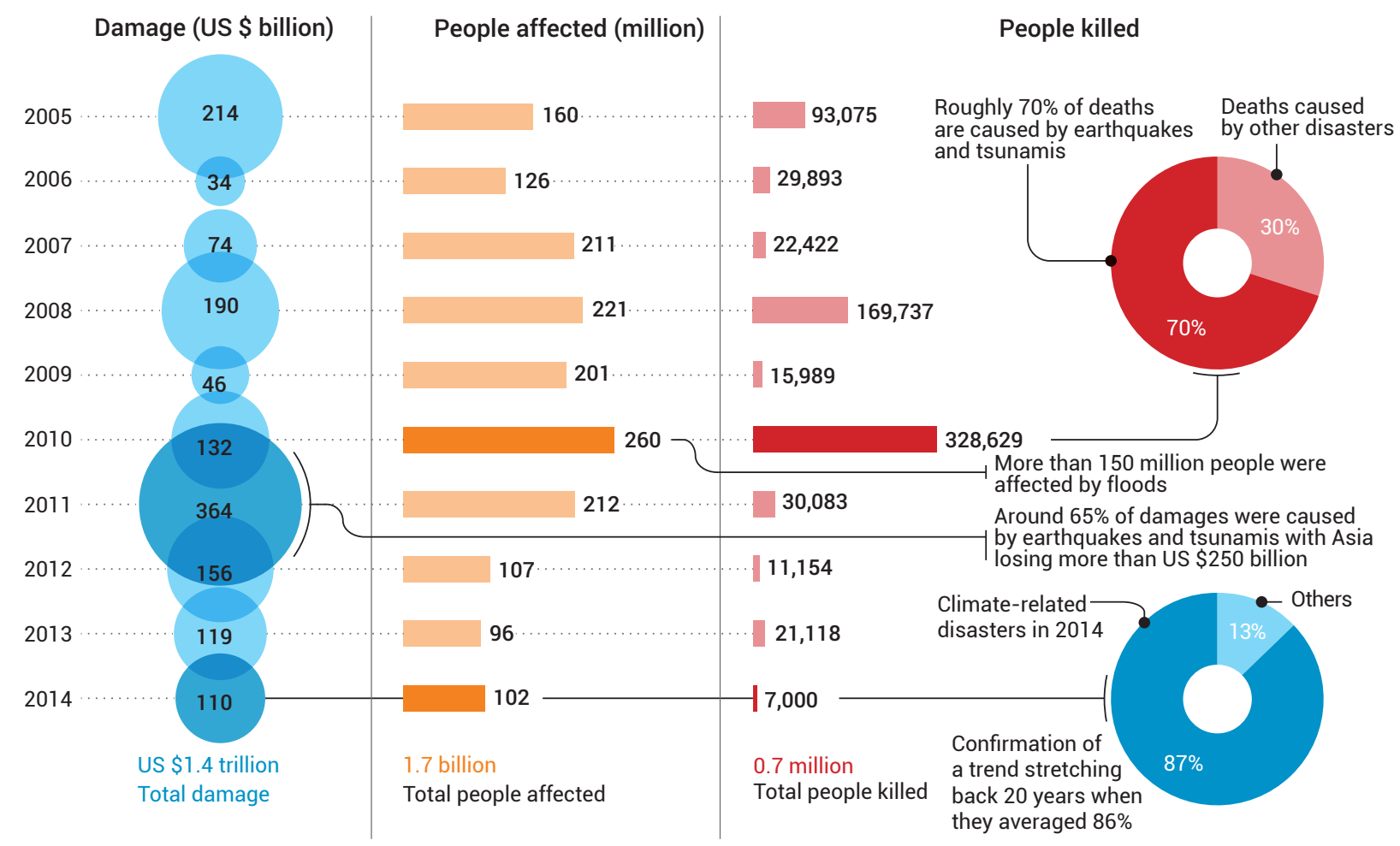

Source: United Nations Office for Disaster Risk Reduction [UNISDR] (2014). 
Climate change affects the environmental fate, behaviour and toxicity of chemicals and heavy metals by modifying the physical, chemical and biological conditions that determine how they move through and behave in the environment (atmosphere, water, soil/ sediment and biota). These changes have the potential to produce adverse impacts on human health and other life on Earth. $\{4.3 .1\}$

Peatlands store twice as much carbon as all global forest biomass combined. Climate change is thawing permafrost in boreal peatlands in and around the Arctic Circle, producing high carbon emissions. In addition, drainage and agricultural use of tropical peatlands is causing wildfires and releasing significant quantities of $\mathrm{CO}_{2}$ and methane (established but incomplete). Altogether, about 15 per cent of peatlands worldwide had been drained by 2015 . Peatlands currently contribute approximately 5 per cent of annual global carbon emissions. $\{9.6\}$

Climate change will amplify existing risks and create new ones for natural and human systems; these risks are unevenly distributed (well established). Risks are generally greater for developing countries (particularly SIDS) and for disadvantaged people and communities in countries at all levels of development. Climate-related hazards interact with and amplify existing factors that contribute to differential vulnerability and to the exposure of human and natural systems: both the resilience of these systems and their ability to adapt are negatively affected. \{Chapter 2 , ExecSum, 2.7.4\}

Society-wide risks associated with environmental degradation and the effects of climate change are generally more profound for people who are already socially and economically disadvantaged, particularly in developing countries (established but incomplete). \{SPM, p. 6\} These risks are greatest for people who are directly dependent on natural resource sectors (e.g. agricultural, pastoral and forest communities). Those experiencing multiple forms of inequality, marginalization and poverty, including poor women, sexual minorities and disadvantaged racial/ethnic minorities, are most exposed to these risks and are least able to recover from economic and environmental losses. \{Chapter 2, ExecSum, 2.7.3\}

Climate change poses risks to human societies through impacts on food and water security (established but incomplete), as well as impacts on human security, health, livelihoods and infrastructure. Rising temperatures will generally diminish crop yields, particularly in low-latitude developing countries, although some temperate regions may benefit from warmer temperatures and longer growing seasons in the medium term. Water scarcity may limit the extent to which the expansion of irrigation could counter climate threats to crop yields and force reversion to rain-fed agriculture in a number of important crop-producing regions by the end of this century, with further consequences for crop production. Overexploitation is already compromising groundwater in several large aquifers critical to agriculture. $\{4.4 .3\}$

The increasing scale, global reach and speed of change of the drivers of environmental change present urgent challenges with respect to managing environmental problems, including those specifically related to climate change (well established). Many of the impacts of environmental change are serious or irreversible and may lead to loss of livelihoods, increased morbidity and mortality, and economic slowdown; in many instances climate change is already driving loss of social resilience, human mass migration and violent conflict. Scientific understanding of adverse, increasingly high-impact change continues to grow. Although existing knowledge is still incomplete, it can contribute to the development of the measures urgently required for more effective adaptation, especially in the case of populations and regions in vulnerable situations. $\{2.7 .3$; SPM, p. 7$\}$

\subsection{Technology}

Growth in technological innovation since the 1990s has been unprecedented both globally and historically, providing many benefits but with negative impacts on some people's lives (established but incomplete). Some technological and social innovations can reduce the environmental pressures associated with unsustainable consumption and production. Enhancing access to existing environmental technologies that are adapted to domestic circumstances could help countries to achieve environmental objectives more quickly. Application of precautionary approaches, according to international agreements (where applicable), to new technological innovations can reduce unintended negative consequences for human and ecosystem health. \{SPM p.6\}

Technological advances have had both positive and negative effects (well established). Fossil fuel burning has accelerated economic development and lifted the standard of living of billions of people in both industrialized and developing countries. However, it is also a major driver of climate change. There are now current and emerging technologies that provide emission-free energy, creating more efficient and less 
resource-intensive processes and helping to clean up the environment. \{Chapter 2, ExecSum, 2.6.1, 2.6.2\}

\section{Technological advances have unintended} consequences, making it difficult to determine whether they will have long-term positive and/or negative impacts (established but incomplete). Scientific analysis of technology issues often fails to capture the full implications of new technologies, especially when these technologies are widely diffused. \{Chapter 2, ExecSum, 2.6.3, 2.6.4\} For example, geo-engineering proposals designed to remove GHG emissions from the atmosphere require increased energy use. $\{23.3 .2\}$ Nanotechnology, by decreasing the particle size of a material and increasing its reactivity, may change the material's properties in ways that are not yet understood. A number of questions remain concerning the toxicity of nanoparticles to humans and the environment (United Nations Environment Programme [UNEP] 2019a, pp. 313-315). \{4.3.3\}

\subsection{Interactions across the five drivers}

\section{The driving forces of environmental degradation are strongly intertwined, complex, and spread widely and unevenly across the world (Table 2.1) (well established). Responses by established governance structures at all levels - urban and rural, local, national, regional, global and supranational - have so far been inadequate to constrain or redirect these forces to better align them with the principles of sustainable development. \{2.1.1; SPM, p. 6\}}

Table 2.1: Interrelationships across the drivers

\begin{tabular}{|c|c|c|c|c|c|}
\hline & Population growth & Economic growth & Technological change & Climate change & Urbanization \\
\hline $\begin{array}{l}\text { Population } \\
\text { growth }\end{array}$ & - & $\begin{array}{l}\text { Negative impact } \\
\text { due to delay in the } \\
\text { demographic window } \\
\text { of opportunity }\end{array}$ & $\begin{array}{l}\text { Population growth } \\
\text { fosters technological } \\
\text { innovation, to } \\
\text { accommodate the } \\
\text { additional demands. } \\
\text { Alternatively, it could } \\
\text { lead to lower savings } \\
\text { and investment due to } \\
\text { high dependency rates }\end{array}$ & $\begin{array}{l}\text { Population } \\
\text { growth increases } \\
\text { environmental } \\
\text { pressure, and climate } \\
\text { change }\end{array}$ & $\begin{array}{l}\text { Increased pressure } \\
\text { on urban areas, more } \\
\text { people might move to } \\
\text { urban areas }\end{array}$ \\
\hline $\begin{array}{l}\text { Economic } \\
\text { growth }\end{array}$ & $\begin{array}{l}\text { Higher GDP and } \\
\text { development in } \\
\text { general is associated } \\
\text { with lower fertility } \\
\text { rates }\end{array}$ & - & $\begin{array}{l}\text { Economic growth } \\
\text { is associated with } \\
\text { increased investment } \\
\text { and technological } \\
\text { innovation }\end{array}$ & $\begin{array}{l}\text { Increased economic } \\
\text { output is associated } \\
\text { with increased } \\
\text { environmental } \\
\text { pressure }\end{array}$ & $\begin{array}{l}\text { Growth will push } \\
\text { towards increased } \\
\text { urbanization }\end{array}$ \\
\hline $\begin{array}{l}\text { Technological } \\
\text { change }\end{array}$ & $\begin{array}{l}\text { Technological } \\
\text { innovation is } \\
\text { associated with } \\
\text { increased capacity to } \\
\text { lower fertility rates }\end{array}$ & $\begin{array}{l}\text { Innovation is } \\
\text { associated with } \\
\text { increased growth in } \\
\text { GDP }\end{array}$ & - & $\begin{array}{l}\text { Current trends } \\
\text { show an increase in } \\
\text { green technological } \\
\text { innovation, thus } \\
\text { lowering pressure per } \\
\text { unit of output }\end{array}$ & $\begin{array}{l}\text { Technological change } \\
\text { can contribute } \\
\text { to processes of } \\
\text { urbanization or it can } \\
\text { help to decrease the } \\
\text { migration patterns } \\
\text { through better access } \\
\text { to technologies and } \\
\text { communication }\end{array}$ \\
\hline $\begin{array}{l}\text { Climate } \\
\text { change }\end{array}$ & $\begin{array}{l}\text { Climate change } \\
\text { increases mortality } \\
\text { rates and negatively } \\
\text { affects health }\end{array}$ & $\begin{array}{l}\text { There are costs } \\
\text { associated with } \\
\text { climate change that } \\
\text { limit economic growth }\end{array}$ & $\begin{array}{l}\text { Climate change } \\
\text { pressures foster } \\
\text { adaptive technological } \\
\text { innovation }\end{array}$ & - & $\begin{array}{l}\text { Effects of climate } \\
\text { change on rural } \\
\text { communities puts } \\
\text { pressure on migration } \\
\text { towards urban areas }\end{array}$ \\
\hline Urbanization & $\begin{array}{l}\text { Urbanization is } \\
\text { associated with } \\
\text { lower fertility rates } \\
\text { (due to access to } \\
\text { better health care and } \\
\text { education) }\end{array}$ & $\begin{array}{l}\text { Urbanization is } \\
\text { strongly associated } \\
\text { with higher economic } \\
\text { output }\end{array}$ & $\begin{array}{l}\text { Urbanization will lead } \\
\text { to intensification of } \\
\text { technology use due } \\
\text { to greater population } \\
\text { density }\end{array}$ & $\begin{array}{l}\text { There is no clear } \\
\text { causal link, but there } \\
\text { is an association } \\
\text { between urbanization } \\
\text { and higher emissions }\end{array}$ & - \\
\hline
\end{tabular}




\section{References}

Birkmann, J., Welle, T., Solecki, W., Lwasa, S. and Garschagen, M. (2016) Boost resilience of small and mid-sized cities. Nature 537(7622), 605608. http://dx.doi.org/10.1038/537605a.

Canuto, O. (2010). Towards a Switchover of Locomotives in the Global Economy. Economic Premise. World Bank. http://documents.worldbank org/curated/en/694391468174866224/pdf/568290BRI0EP330Box3537 39B01PUBLIC1.pdf.

Chancel, L. and Piketty, T. (2015). Carbon and Inequality: From Kyoto to Paris. Trends in the Global Inequality of Carbon Emissions (1998-2013) and Prospects for an Equitable Adaptation Fund. Paris: Paris School of Economics. http://piketty.pse.ens.fr/files/ChancelPiketty2015.pdf.

Earth Policy Institute (2011). Data highlights: Education leads to lower fertility and increased prosperity. Rutgers University. http://www.earthpolicy.org/data_highlights/2011/highlights 13 Accessed 11 September 2019.

Elliott, J., Deryng, D., Müller, C., Frieler, K, Konzmann, M., Gerten, D et al. (2013). Constraints and potentials of future irrigation water availability on agricultural production under climate change. Proceedings of the National Academy of Sciences 111(9), 3239-3244. https://doi. org/10.1073/pnas. 1222474110.

Le Quéré, C., Andrew, R.M., Canadell, J.G., Sitch, S., Korsbakken, J.I., Peters, G.P. et al. (2016). Global carbon budget 2016. Earth System Science Data 8(2), 605. https://doi.org/10.5194/essd-8-605-2016.

Melchiorri, M., Florczyk, A., Freire, S., Schiavina, M., Pesaresi, M. and Kemper, T. (2018). Unveiling 25 years of planetary urbanization with remote sensing: Perspectives from the global human settlement layer. Remote Sensing 10(5), 768. https://doi.org/10.3390/rs10050768.

Munich RE (2017). Natural disasters: The year in figures. https://www. munichre.com/topics-online/en/climate-change-and-natural-disasters/ natural-disasters/overview-natural-catastrophe-2016 html. Accessed 20 September 2019.

Pesaresi, M., Melchiorri, M., Siragusa, A. and Kemper, T. (eds.) (2016). Atlas of the Human Planet 2016 Mapping Human Presence on Earth with the Global Human Settlement Layer. Brussels: European Union. http://ghsl.jrc.ec.europa.eu/atlas20160verview.php.

United Nations (2014). World Urbanization Prospects: 2014

Revision, Highlights. New York, NY. https://www.oecd-ilibrary.org/ docserver/527e5125-en.pdf?expires $=1575367219$ \&id=id\&accname=ocid 54015570\&checksum=B024DD0493508AE28890BB7007D573EF.
United Nations (2018). World Urbanization Prospects: The 2018 Revision. New York, NY. https://population.un.org/wup/Publications/ Files/WUP2018-KeyFacts.pdf.

United Nations Environment Programme (2019a). Global Chemicals Outlook II: From Legacies to Innovative Solutions. Nairobi. http://wedocs.unep.org/bitstream/handle/20.500.11822/28113/GCOII. pdf? sequence $=1$ \&isAllowed $=y$.

United Nations Environment Programme (2019b). Global Environment Outlook - GEO-6: Healthy Planet, Healthy People. Nairobi. https://wedocs.unep.org/bitstream/handle/20.500.11822/27539/ GE06_2019.pdf?sequence=1\&isAllowed=y.

United Nations Human Settlement Programme (2012). State of Latin America and Caribbean cities 2012: Towards a New Urban Transition. Nairobi. http://mirror.unhabitat.org/pmss/getElectronicVersion. aspx?nr=3386\&alt=1.

United Nations Human Settlement Programme (2014a). Urbanization and Sustainable Development: Towards A New United Nations Urban Agenda. CEB/2014/HLCP-28/CRP.5. New York, NY Agenda Item 6: New UN Urban Agenda https://habnet.unhabitat.org/sites/default/files/oo/ urbanization-and-sustainable-development.pdf

United Nations Human Settlements Programme (2014b). Sustainable Urban Development and Agenda 2030: UN-Habitat's Programme Framework: PSUP; Transforming the Lives of One Billion Slum Dwellers. Nairobi. https://unhabitat.org/sustainable-urban-development-andagenda-2030-un-habitats-programme-framework-psup-transforming-thelives-of-one-billion-slum-dwellers/\#.

United Nations Human Settlement Programme (2016a). World Citie Report. Urbanization and Development: Emerging Futures. Nairobi. https://unhabitat.org/sites/default/files/download-manager-files/WCR2016-WEB.pdf.

United Nations Human Settlements Programme (2016b). Pretoria Declaration on Informal Settlements. Nairobi. https://unhabitat.org/ pretoria-declaration-on-informal-settlements/\#

United Nations Office for Disaster Risk Reduction (2014). The economic and human impact of disasters in the last 10 years.

https://ec.europa.eu/europeaid/sites/devco/files/infograph-economichuman-impact-2005-2014_en.pdf

World Bank (2017). World development indicators. http://datatopics worldbank.org/world-development-indicators/ Accessed 24 September 2019. 